NASA Technical Memorandum 107470

AIAA-97-2688

\title{
Hot Fire Ignition Test With Densified Liquid Hydrogen Using a RL10B-2 Cryogenic $\mathrm{H}_{2} / \mathrm{O}_{2}$ Rocket Engine
}

Nancy B. McNelis

Lewis Research Center

Cleveland, Ohio

and

Mark S. Haberbusch

Ohio Aerospace Institute

Cleveland, Ohio

Prepared for the

33rd Joint Propulsion Conference \& Exhibit

cosponsored by AIAA, ASME, SAE, and ASEE

Seattle, Washington, July 6-9, 1997

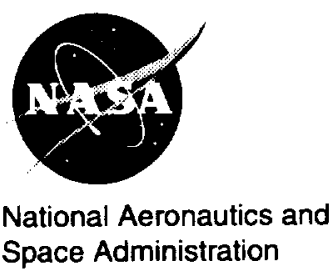


• 


\title{
HOT FIRE IGNITION TEST WITH DENSIFIED LIQUID HYDROGEN USING A RL10B-2 CRYOGENIC $\mathrm{H}_{2} / \mathrm{O}_{2}$ ROCKET ENGINE
}

\author{
Nancy B. McNelis \\ National Aeronautics and Space Adminstration \\ Lewis Research Center \\ Cleveland, Ohio 44135 \\ and \\ Mark S. Haberbusch * \\ Ohio Aerospace Institute \\ 22800 Cedar Point Road \\ Cleveland, Ohio 44142
}

\begin{abstract}
$\underline{\text { Abstract }}$
Enhancements to propellants provide an opportunity to either increase performance of an existing vehicle, or reduce the size of a new vehicle. In the late 1980's the National AeroSpace Plane (NASP) reopened the technology chapter on densified propellants, in particular hydrogen. Since that point in time the NASA Lewis Research Center (LeRC) in Cleveland, Ohio has been leading the way to provide critical research on the production and transfer of densified propellants. On October 4, 1996 NASA LeRC provided another key demonstration towards the advancement of densified propellants as a viable fuel. Successful ignition of an RL10B-2 engine was achieved with near triple point liquid hydrogen.
\end{abstract}

\section{Introduction}

This paper describes the successful ignition test of the cryogenic hydrogen/oxygen RL10B-2 rocket engine using densified liquid hydrogen at near triple point conditions and the potential impact of this test to the aerospace industry via engine and vehicle performance analyses. This demonstration test represents the next step in the advancement of densified propellant technology, the development of an engine that can operate using densified propellants.

Increased demand for launch vehicles for satellite deployment by the private sector and by governments through out the world has generated a fertile yet competitive environment from which advanced aerospace technologies are being incorporated into flight vehicles. One such technology on the verge of being utilized is the use of

'Presently at Sierra Lobo Inc., Propellant Densification Systems, Strongsville, Ohio 44136. densified cryogenic propellants such as hydrogen and oxygen. The main advantage of densified cryogenic propellants is the increase in propellant mass fraction. Increased propellant mass fraction means increased payload mass to orbit and more revenue.

Densified cryogenic propellant technology development began in the early 1960 's. Opportunities to utilize the technology included the Saturn IV upper stage and the Space Shuttle. However the technology was not considered advanced enough to be incorporated into the design cycle of these vehicles. More recently, research conducted by NASA for the National AeroSpace Plane program advanced slush hydrogen technology to the point that slush was selected as the fuel for the single-stage-to-orbit NASP X-30. These technology advancements focused on large scale slush production, vehicle related component testing, and computer code modeling. However the NASP program was cancelled before full scale engine testing utilizing slush hydrogen could be conducted.

A key issue that has not been adequately addressed is the demonstration of a rocket engine operating with densified propellants. During a recent test program, an opportunity arose to obtain some data using densified hydrogen with a Pratt \& Whitney RL10B-2 engine. NASA in cooperation with McDonnell Douglas and Pratt \& Whitney conducted two hot fire ignition tests in the Spacecraft Propulsion Research Facility (B2) at NASA Plum Brook Station, Sandusky, Ohio.

The first ignition test was called the nominal test. The inlet conditions and operating procedures were all

"Copyright $\bigcirc$ by the American Institute of Aeronautics and Astronautics, Inc. No copyright is asserted in the United States under Title 17, U.S. Code. The U.S. Government has a royalty-free license to exercise all rights under the copyright claimed herein for Governmental Purposes. All other rights are reserved by the copyright owner." 
considered "nominal" for the RL10B-2. The test was also the first hot fire of the RL10B-2 in the NASA Plum Brook $B 2$ facility and provided a baseline to demonstrate that the engine and facility were operating properly. The second test that is presented was the densified hydrogen ignition hot fire test. This test was conducted under essentially the same conditions as the nominal test except for the difference in the hydrogen density and temperature.

The results of the two ignition tests are compared in this paper. Engine and vehicle performance analyses are also presented to quantify the potential performance benefits of densified propellants in an overall system.

\section{Symbols}

g gravitational constant of earth

Isp delivered specific impulse

$m_{d}$ dead weight mass

$m_{1}$ payload mass

$\mathrm{m}_{\mathrm{o}}$ initial mass

$m_{p}$ propellant mass

$\Delta \mathbf{v}$ delta velocity

$\delta \quad$ dead weight ratio

$\lambda$ payload ratio

\section{Subscripts}

1 first stage

2 second stage

i first or second stage

\section{Experimental Apparatus}

The ignition tests were conducted in the NASA Spacecraft Propulsion Research (B2) Facility. The RL10B-2 rocket engine that was tested is shown mounted inside the B2 facility vacuum chamber in Fig. 1. The B2 facility was designed to test full-scale upper-stage rockets up to $200000 \mathrm{lb}$ thrust in a simulated space environment. The B2 facility was initially used in the late 1960's and early 1970 's to test the Centaur vehicle and is currently being utilized by several U.S. aerospace companies for the

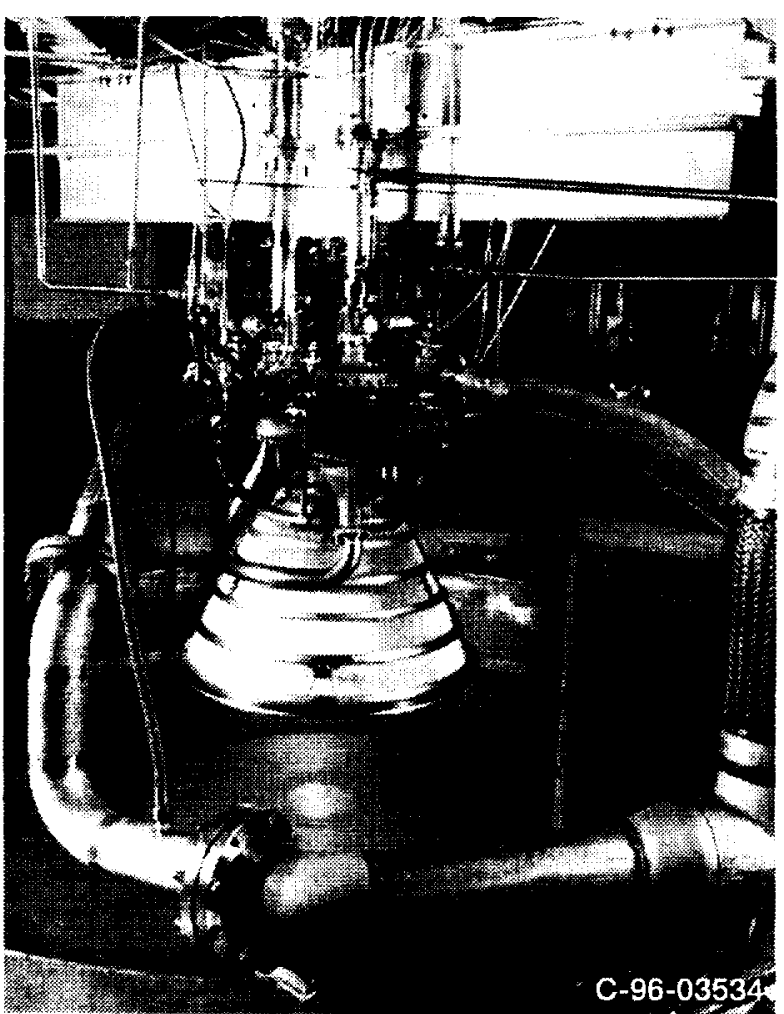

\section{Figure 1 - RL10B-2 Rocket Engine Mounted in the B-2 Facility}

development of advanced upper-stage space vehicles and rocket engines.

A simplified drawing of the test configuration is shown in Fig. 2. The vacuum chamber is $38 \mathrm{ft}$ in diameter, $62 \mathrm{ft} \mathrm{high,} \mathrm{and} \mathrm{is} \mathrm{constructed} \mathrm{out} \mathrm{of} \mathrm{stainless} \mathrm{steel.} \mathrm{A}$ mechanical vacuum pumping system is used to evacuate the vacuum chamber. It consists of one $28100 \mathrm{cfm}$ blower (first stage), two $1875 \mathrm{cfm}$ blowers (second stage), and four $728 \mathrm{cfm}$ mechanical vacuum pumps (third stage).

The rocket engine exhaust from the ignition tests was directed into the spray chamber located below the vacuum test chamber. The vacuum test chamber and spray chamber are connected via an $11 \mathrm{ft}$ diameter, $37 \mathrm{ft}$ long inconel diffuser duct. The vacuum test chamber and the spray chamber are isolated from one another by a $11 \mathrm{ft}$ valve at the bottom of the diffuser. The $420000 \mathrm{ft}^{3}$ spray chamber was filled with $70 \mathrm{ft}$ of water prior to testing and was evacuated for the testing using steam ejectors.

Inside the vacuum test chamber were mounted a 250 gal liquid hydrogen $\left(\mathrm{LH}_{2}\right)$ test tank, a 40 gal liquid oxygen (LOX) test tank, propellant feed ducts, and an 


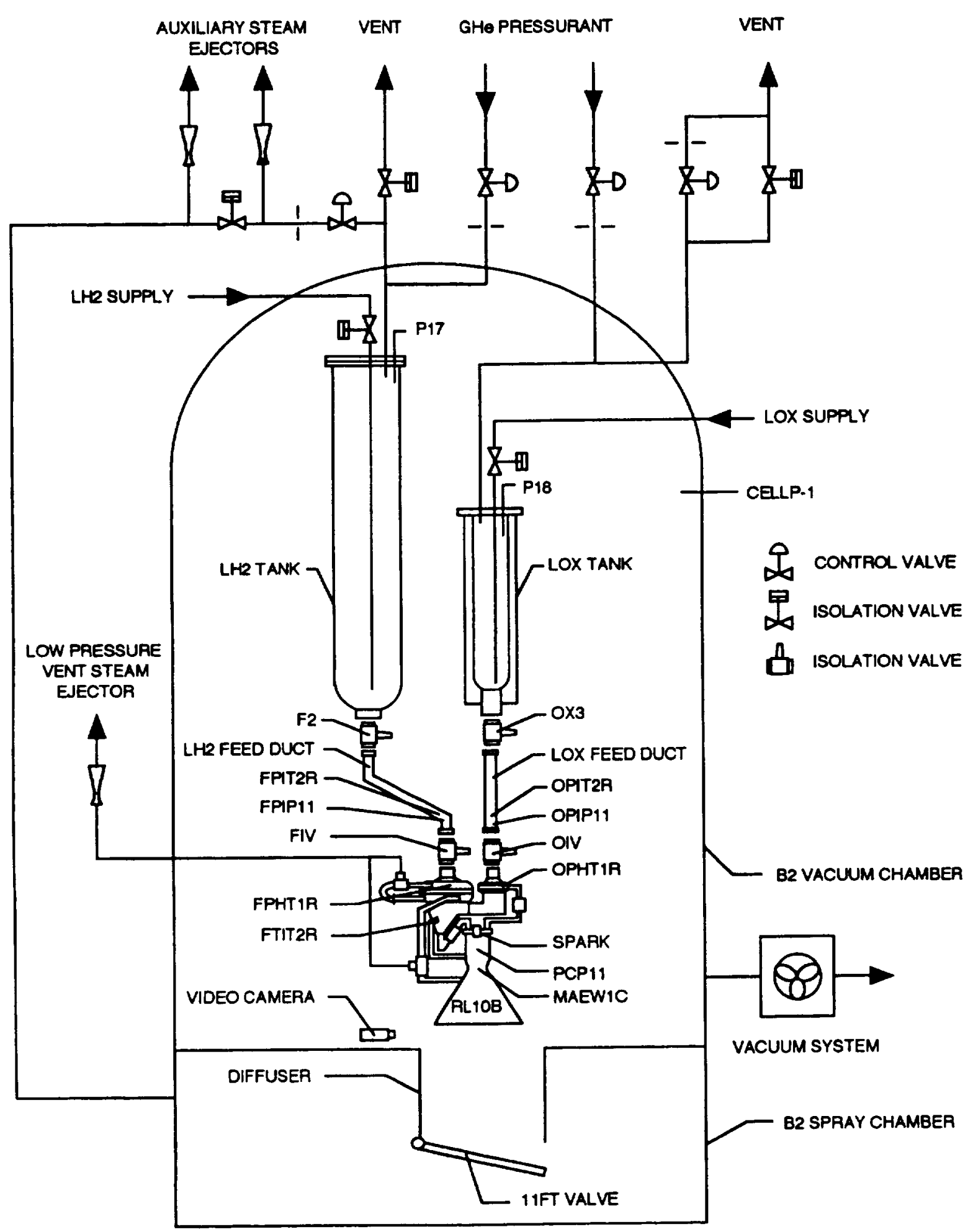

DRAWING NOT TO SCALE

Figure 2 - Simplified RL10B Densified Hydrogen Ignition Test Configuration 
RL10B-2 rocket engine. $\mathrm{LH}_{2}$ and $\mathrm{LOX}$ were supplied to their respective test tanks via a $14000 \mathrm{gal} \mathrm{LH}_{2}$ dewar and a 12000 gal LOX dewar located outside of the B2 test building. Gaseous helium (GHe) pressurant gas was supplied to each test tank via separate pressurant gas control systems supplied by a $70000 \mathrm{scf}$ GHe tube trailer. For the densified hydrogen ignition test steam ejectors were utilized to vacuum pump on the hydrogen test tank to densify the hydrogen.

The $\mathrm{LH}_{2}$ test tank was isolated from the $\mathrm{LH}_{2}$ feed duct by a shutoff valve mounted below the tank (F2). The LOX test tank was also isolated from the LOX feed duct by a shutoff valve (OX3). The $\mathrm{LH}_{2}$ feed duct was constructed out of 2.5 in. diameter, $0.065 \mathrm{in}$. wall thickness, 300 series stainless steel tubing. The LOX feed duct was constructed out of 3 in. diameter, 0.065 in. wall thickness, 300 series stainless steel tubing.

A detailed propellant flow schematic of the RL10B-2 is shown in Fig. 3. The two-stage centrifugal fuel turbopump is isolated from the fuel feed duct with the fuel pump inlet shutoff valve (FIV). The single-stage centrifugal oxidizer pump is isolated from the LOX feed duct with the oxidizer pump inlet shutoff valve (OIV). The fuel pump is chilled down prior to ignition by flowing $\mathrm{LH}_{2}$ through the pump and discharging the propellant out the fuel pump interstage cooldown valve and the fuel pump discharge cooldown valve and into the low pressure steam ejector vent. For the two tests conducted in this report the steam ejectors were not activated and the fuel was discharged to ambient pressure. To cooldown the LOX pump, LOX was discharged through the injector into the $\mathrm{B} 2$ vacuum test chamber. For further details on the characteristics of the RL10B-2 the reader is referred to Ref. 1 .

\section{Instrumentation and Data Systems}

Strain-gage pressure transducers with an accuracy of \pm 1 percent of full scale were used to measure several parameters. The $\mathrm{LH}_{2}$ test dewar pressure (P17), LOX test dewar pressure (P18), fuel pump inlet pressure (FPIP11), and combustion chamber pressure (PCP11) were measured with separate 0 to 50 psia transducers. The oxidizer pump inlet pressure (OPIP11) was measured with a 0 to 100 psia transducer. Vacuum test chamber pressure

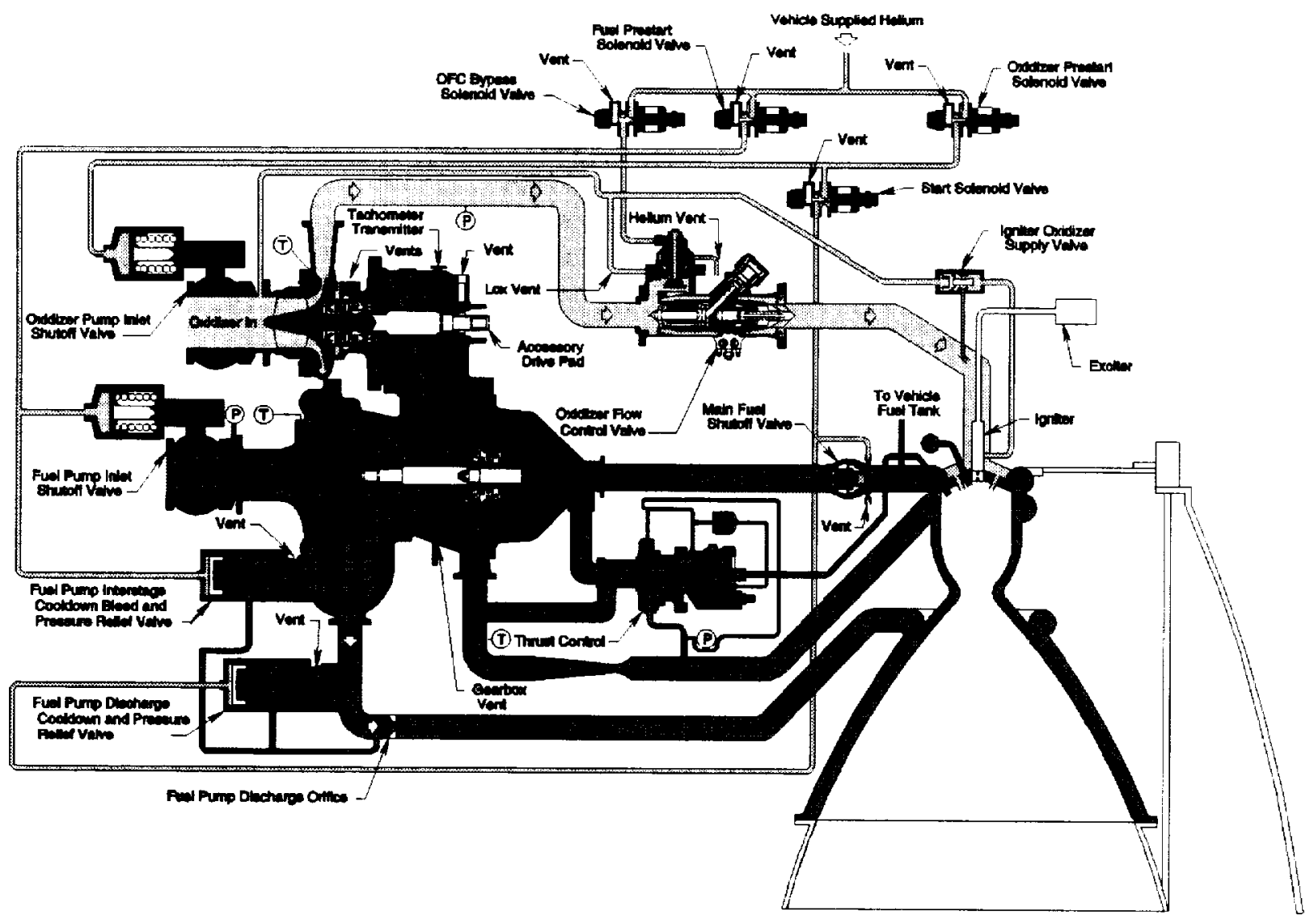

Figure 3 - RL10B-2 Engine Propellant Flow Schematic 
(CELLP1) was measured using a Convection gage with a range of $1 \times 10^{-4}$ to 990 torr and an accuracy of 2 significant digits.

The fuel pump inlet fluid temperature (FPIT2R) and the oxidizer pump inlet fluid temperature (OPIT2R) were measured using silicon diode temperature sensor probes that were inserted into the respective feed ducts upstream of the inlet valves. The accuracy of the silicon diode temperature sensors was $\pm 0.2^{\circ} \mathrm{R}$. The fuel pump housing temperature (FPHT1R) and the oxidizer pump housing temperature (OPHT1R) were measured with platinum resistance thermometers with an accuracy of $\pm 3.0^{\circ} \mathrm{R}$. The pump housing temperature sensors were the same sensors that are used for flight operations. The spark plug gap voltage (SPARK) was a direct measurement of the spark voltage in the ignitor. The accuracy of the measured voltage is within $0.1 \mathrm{~V}$.

Twotypes of data systems were utilized. The ESCORT data recording system recorded 188 channels of data at $1 \mathrm{~Hz}$ and 64 channels of data at $10 \mathrm{~Hz}$. The Masscomp data system recorded 50 channels of data at a recording rate of $1000 \mathrm{~Hz}$. The spark plug gap voltage and the combustion chamber pressure were recorded at $1000 \mathrm{~Hz}$.

\section{Test Procedure}

The operating procedures for hot firing an RL10B-2 rocket engine are fairly complex and involve many detailed steps. The intent of this section is to give an overview of the significant procedural steps used for this testing and the order in which the steps occurred. The two sets of test procedures are for the densified hydrogen test and the nominal test. The only major difference between the two tests is the density of the hydrogen.

\section{Densified Hydrogen Test}

The first step of the test procedure was to evacuate the vacuum chamber to $\sim 2$ torr to minimize the heat leak into the test tanks using the mechanical vacuum system. The spray chamber was evacuated to $\sim 45$ torr using both auxiliary steam ejector trains and then maintained at this pressure with only one train. The propellants were then loaded into the test tanks. The liquid hydrogen test tank was filled with $\sim 239$ gal of liquid hydrogen and the liquid oxygen test tank was filled with 35 gal of LOX. Both test tank shutoff valves (F1 and $\mathrm{OX} 3$ ) where open during the fill and the inlet shutoff valves (FIV, OIV) were closed thus allowing propellants to fill the feed ducts.

The propellants were then conditioned to the appropriate saturated starting conditions as required to conduct the test. The LOX tank pressure was controlled to $22.9 \mathrm{psia}$ and the propellant was allowed to warm to the saturation temperature based on tank pressure. The liquid hydrogen was conditioned by vacuum pumping on the $\mathrm{LH}_{2}$ test tank using the other train of the auxiliary steam ejectors. Reducing the vapor pressure caused evaporative cooling of the liquid hydrogen and lowered the temperature of the liquid hydrogen. The final vapor pressure of the liquid hydrogen was 1.94 psia.

Once the propellants were conditioned, video recording of the exit plane of the engine bell was initiated. The vacuum chamber pressure was then raised to 45 torr to equalize with the spray chamber pressure. The $11 \mathrm{ft}$ valve was then opened. The propellant tanks were then pressurized to give the proper pump inlet conditions prior to engine pre-start. The hydrogen tank was ramped to $24.4 \mathrm{psia}$ and the LOX tank was ramped to 43.8 psia. Helium pressurant gas was used for both propellants. ESCORT data recording was initiated.

The sequencer was then activated and the countdown started at T-60.0 sec. The sequencer automatically controlled all engine valves during the ignition test per a pre-programmed set of sequential instructions. These instructions included the following steps. At T-50.0 sec the fuel pump pre-start signal was initiated. At T-45.0 sec the LOX pump pre-start signal was initiated. The engine pre-start procedures involve flowing propellants through their respective pumps to chilldown the pumps and prevent cavitation during startup. The fuel pre-start flow was directed out of the engine to the low-pressure vent. The LOX pre-start flow was dumped directly into the vacuum chamber.

At T-2.0 sec the Masscomp data acquisition system was activated. At T-0 sec the engine start signal was given. The ignitor signal was activated at $\mathrm{T}+0.082 \mathrm{sec}$ and de-activated at $T+0.550 \mathrm{sec}$. Engine shutdown occurred at $\mathrm{T}+1.0$ sec. At engine shutdown propellant flow was shutoff from the engine.

\section{Nominal Test}

For the nominal ignition test the liquid hydrogen test tank was filled with approximately $135 \mathrm{gal}$ of $\mathrm{LH}_{2}$ and 34 gal of LOX were loaded into the LOX test tank. The propellants were then conditioned to the appropriate saturated starting conditions. For the nominal ignition test the $\mathrm{LH}_{2}$ tank pressure was controlled to 17.5 psia and the LOX tank pressure to 28.0 psia while the propellants saturated at these pressures.

At this point similar procedures between the nominal test and the densified test were conducted. Minor differences between the two tests include pressurizing the $\mathrm{LH}_{2}$ 
tank to 29.8 psia and the LOX tank to 45.5 psia for the nominal test. Also, the ignitor was activated at $\mathrm{T}+0.270 \mathrm{sec}$ and de-activated at $\mathrm{T}+0.870 \mathrm{sec}$ for the nominal test.

The minor differences in $\mathrm{LH}_{2}$ tank pressurization levels and the ignition times between the two tests were a result of increasing the probability of ignition which was the ultimate goal of the test. Since there was only one opportunity to conduct the densified hydrogen test it was important to generate the best possible conditions to ignite. The reduced $\mathrm{LH}_{2}$ tank pressure was predicted to cause the mixture ratio of oxygen to hydrogen to increase slightly thus increasing the amount of oxygen available for ignition. The ignitor was activated sooner in the densified hydrogen test to increase the number of sparks early in the sequence, thus also increasing the possibility of ignition, in case the ignition window was earlier in the start sequence as a result of increased hydrogen mass in the combustion chamber due to densifying the hydrogen.

\section{$\underline{\text { Results and Discussion }}$}

Table I shows the test conditions at engine start for both the densified hydrogen propellant ignition test and the nominal ignition test.

The liquid hydrogen density at the inlet of the fuel pump for the densified ignition test was $4.738 \mathrm{lbm} / \mathrm{ft}^{3}$ and for the nominal test the density was $4.317 \mathrm{lbm} / \mathrm{ft}^{3}$. This is a 9.8 percent increase in liquid hydrogen density over the nominal run.

Once again, the purpose of the testing was to demonstrate the ignition of densified hydrogen in the RL10B-2. The primary indicator of a successful ignition is given by a rapid increase in combustion chamber pressure. The secondary indicator is visual observation of the flame exiting from the bell of the engine. Figures 4 and 5 show the combustion chamber pressure and the spark gap discharge voltage for the densified hydrogen ignition test and the nominal ignition test, respectively. Time zero is when the engine start signal is initiated.
In Fig. 4, the densified test, the combustion chamber pressure starts at 0.9 psia which is the $\mathrm{B} 2$ facility vacuum chamber pressure into which the engine ignites. At $\sim 75$ msec propellant begins to flow into the combustion chamber causing an increase in combustion chamber pressure to about 5 psia. A rapid increase in combustion chamber pressure occurs at 244 msec indicating a successful ignition. The combustion chamber pressure at ignition peaks at 33 psia in about $4 \mathrm{msec}$ and then decays down to about 15 psia for the remainder of the test.

Figure 4 also shows the spark gap voltage being discharged by the spark plug ignitor. The ignitor was programmed to begin discharging a spark at $82 \mathrm{msec}$ instead of the nominal $280 \mathrm{msec}$ to increase the probability of ignition. Each 25 msec decay of the spark gap voltage indicates that a spark has been generated by the ignitor. The spark gap voltage shown in Fig. 4 indicates that combustion began on the 7 th spark.

The nominal ignition test combustion chamber pressure plotted in Fig. 5 shows a rapid pressure increase at $281 \mathrm{msec}$. This indicates a successful ignition on the first spark $1 \mathrm{msec}$ after the ignitor was discharged. The combustion chamber pressure peaked at 14 psia in about $3 \mathrm{msec}$ then steadied out at $\sim 13$ psia for about $300 \mathrm{msec}$ before climbing slightly to 15 psia at the end of the test.

Visual observations of the exit plane of the rocket engine bell with a video camera verified successful engine ignition in both tests. The video showed an exhaust plume from the nozzle exit in both the densified hydrogen test and the nominal test. If the engine had not ignited, a foggy plume of propellants would have been seen flowing from the bell instead of the flame.

\section{Engine Performance Analysis}

An analysis was conducted to illustrate that the potential effects of densified propellants on the specific impulse of the RL10B-2 engine are minimal, and to provide input for the vehicle analysis. The calculations were theoretical

TABLE I.-IGNITION TEST START CONDITIONS

\begin{tabular}{|l|l|c|c|}
\hline \multicolumn{1}{|c|}{ Parameter description } & $\begin{array}{c}\text { Parameter } \\
\text { name }\end{array}$ & $\begin{array}{c}\text { Densified } \\
\text { hydrogen } \\
\text { ignition test }\end{array}$ & $\begin{array}{c}\text { Nominal } \\
\text { ignition } \\
\text { test }\end{array}$ \\
\hline Fuel pump housing temperature & FPHT1R & $58.4 \mathrm{R}$ & $62.8 \mathrm{R}$ \\
Oxidizer pump housing temperature & OPHT1R & $176.0 \mathrm{R}$ & $184.2 \mathrm{R}$ \\
Fuel pump inlet temperature & FPIT2R & $27.5 \mathrm{R}$ & $39.1 \mathrm{R}$ \\
Fuel pump inlet pressure & FPIP11 & $24.1 \mathrm{psia}$ & $29.3 \mathrm{psia}$ \\
Oxidizer pump inlet temperature & OPIT2R & $171.8 \mathrm{R}$ & $177.4 \mathrm{R}$ \\
Oxidizer pump inlet pressure & OPIP11 & $47.5 \mathrm{psia}$ & $46.8 \mathrm{psia}$ \\
External throat tube temperature & MAEW1C & $387 \mathrm{~F}$ & $422 \mathrm{R}$ \\
Fuel turbine inlet temperature & FTIT2R & $376 \mathrm{R}$ & $493 \mathrm{R}$ \\
\hline
\end{tabular}




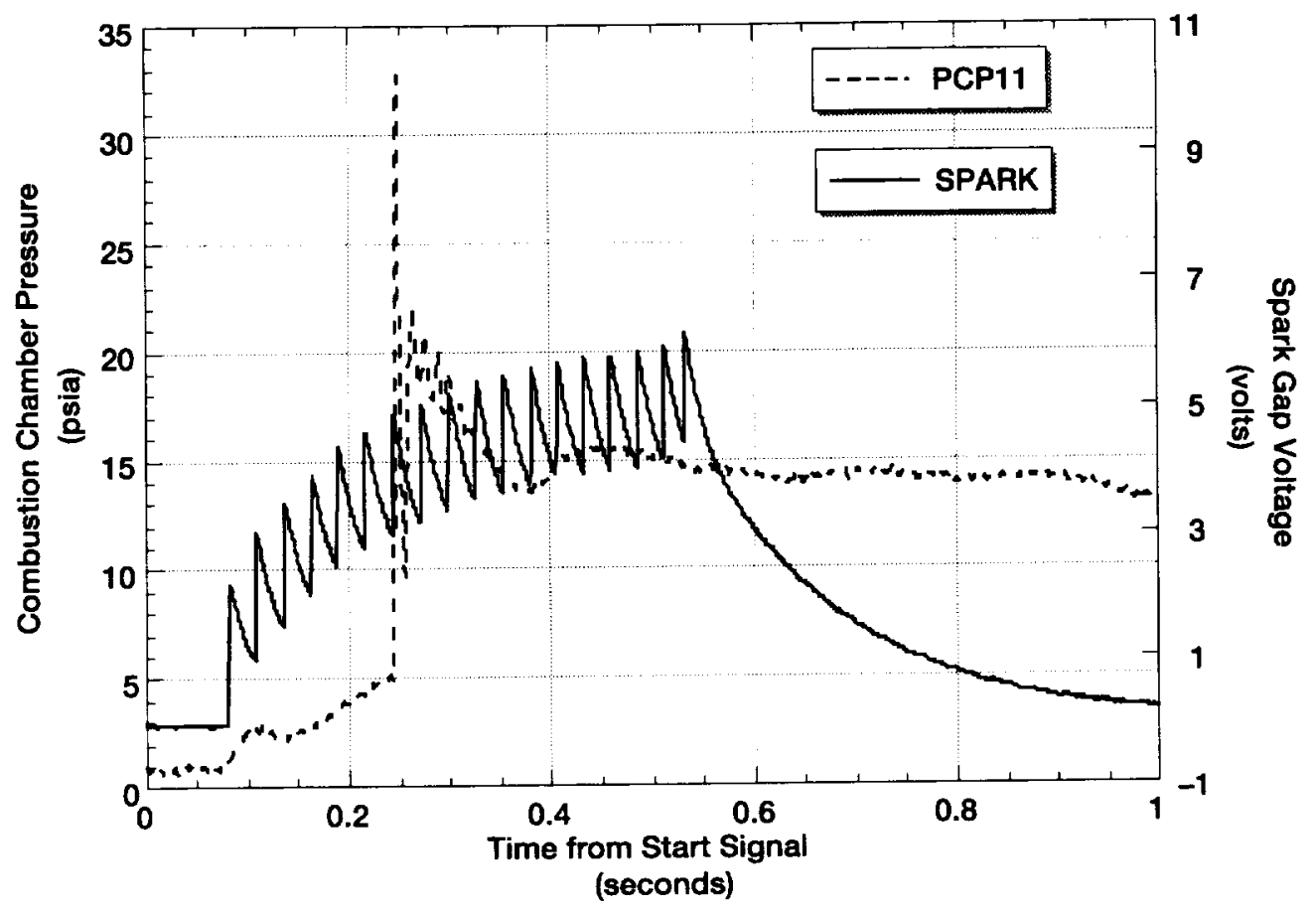

Figure 4 - Combustion Chamber Pressure and Spark Gap Voltage Densified Hydrogen RL10B Ignition Test

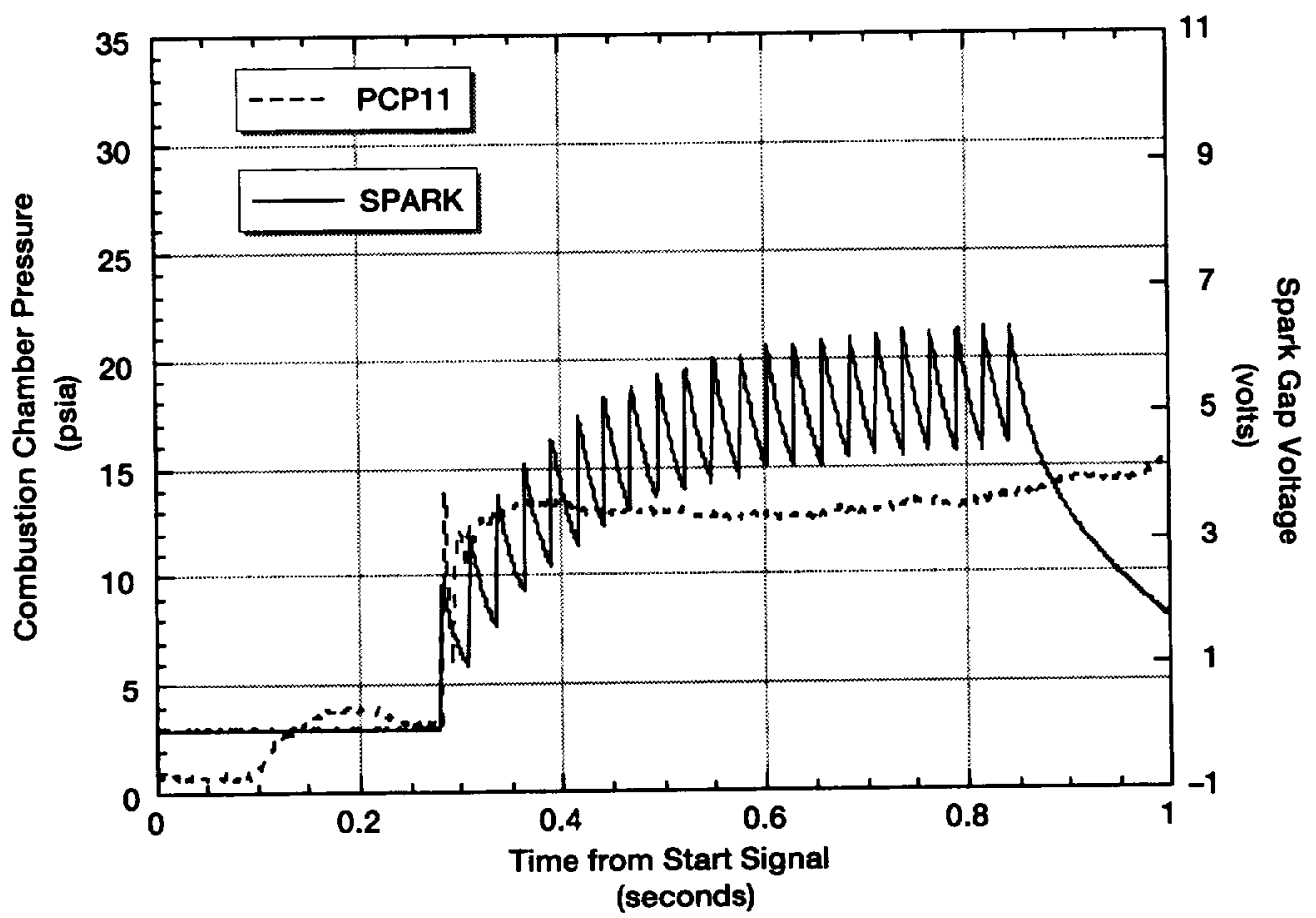

Figure 5 - Combustion Chamber Pressure and Spark Gap Voltage Nominal RL10B Ignition Test 
and were made using CET89, a rocket engine performance prediction code described in Ref. 2 . The two main parameters that were varied in this analysis were the enthalpy of the propellants at the inlet to the injector and the oxidizer to fuel mixture ratio (O/F). For the densified cases the propellant enthalpy at the injector inlet was assumed to differ from the nominal case by the same difference calculated between the storage enthalpies of the densified cases and the nominal case. The propellant densification options considered were triple point liquid hydrogen ( $\mathrm{TP} \mathrm{LH}_{2} \mathrm{~B}$ ), 50 percent solid slush hydrogen $\left(\mathrm{SLH}_{2}\right)$, and oxygen at $140^{\circ} \mathrm{R}$. Because the oxidizer and fuel tank volumes were fixed for the vehicle analysis, it was also assumed that the $\mathrm{O} / \mathrm{F}$ for the densified cases were adjusted from the nominal 6.0 by an amount proportional to the change in density of the densified propellants from the nominal case.

The results of the analysis are given in Table II. Case 1 is the nominal RL10B-2 engine configuration with an $\mathrm{O} / \mathrm{F}$ of 6.0. For this case the theoretical specific impulse was $488.4 \mathrm{sec}$. The nominal delivered specific impulse for the RL10B-2 is 466. . $^{1}$ The ratio of delivered to theoretical specific impulse for the nominal case was used to calculate the delivered specific impulse for the densified cases. The results of the densified cases show that the effect on engine performance is small. In fact, by densifying both the hydrogen and the oxygen, the engine performance essentially remains the same.

\section{Vehicle Performance Analysis}

The benefit of using densified propellants on a launch vehicle is to increase the propellant mass fraction of the vehicle which translates into an increase in payload mass to orbit. This increase in payload mass is calculated here with a simplified launch vehicle performance analysis using the two-stage-to-orbit rocket equation. The performance will be measured in terms of additional pounds of payload to low earth orbit (LEO) that can be obtained with densified propellants as compared to a baseline vehicle which uses normal boiling point propellants. The equations used to calculate the increase in payload mass are taken from Ref. 3 and are shown in Appendix A.

The baseline vehicle used in this analysis is a two stage rocket. The first stage uses the RS-27 RP-1/liquid oxygen engine with an average Isp of $264 \mathrm{sec}$. The second stage is a liquid hydrogen/liquid oxygen rocket powered by the RL10B-2 engine which has a delivered Isp of $466.5 \mathrm{sec}$ at a mixture ratio of 6.0 . This baseline vehicle is designed such that the total vehicle weight, propellant masses, and payload mass are averages of the Atlas/ Centaur and Delta III launch vehicles which were obtained from Ref. 4 . The baseline does not include any increase in vehicle weight for hardware, such as a recirculation manifold, required to integrate the vehicle with the GSE densification unit.

Table III shows the results of the launch vehicle performance calculations. The following six cases are analyzed; (1) baseline, (2) triple point liquid hydrogen (TP $\mathrm{LH}_{2}$ ), (3) 50 percent solid slush hydrogen, (4) densified oxygen at $140{ }^{\circ} \mathrm{R}$, (5) triple point liquid hydrogen and densified liquid oxygen at $140^{\circ} \mathrm{R}$, and (6) 50 percent solid slush hydrogen and densified liquid oxygen at $140^{\circ} \mathrm{R}$. The table gives the mass breakdown of the vehicle for each case. For the densified propellant cases, the vehicle tanks were fixed at the baseline tank volume but loaded with additional propellants. The dead weight mass for both the first and second stage were estimated. The final delta velocity for each case was held constant at $30882 \mathrm{ft} / \mathrm{sec}$ which is approximately 20 percent greater than the orbital velocity required to get to LEO. The higher final orbital velocity used in this simplified analysis is an attempt to compensate for the affects of gravity and drag forces which are not explicitly entered into the rocket equation calculations.

The results of the analysis show that the baseline vehicle can place $15000 \mathrm{lb}$ of payload into LEO using normal boiling point hydrogen and oxygen. When triple point liquid hydrogen is used the payload mass to orbit

TABLE II.-RL10B-2 ANALYTICAL ENGINE PERFORMANCE RESULTS WITH DENSIFIED PROPELLANTS

\begin{tabular}{|l|l|r|r|r|r|r|r|}
\hline \multicolumn{1}{|c|}{ Parameter } & Units & $\begin{array}{c}1 \\
\text { Nominal }\end{array}$ & $\begin{array}{c}2 \\
\text { TP } \\
\text { LH2 }\end{array}$ & $\begin{array}{c}\text { Hydrogen } \\
\text { 50 percent } \\
\text { solids }\end{array}$ & $\begin{array}{c}4 \\
\text { Oxygen } \\
140 \text { R }\end{array}$ & $\begin{array}{c}5 \\
\text { TP LH2 } \\
140 \text { R LOX }\end{array}$ & $\begin{array}{c}6 \\
\text { 50 percent } \\
\text { SLH2 } \\
\text { 140 R LOX }\end{array}$ \\
\hline Hydrogen density & $\mathrm{lbm} / \mathrm{ft}^{3}$ & 4.42 & 4.80 & 5.08 & 4.42 & 4.80 & 5.08 \\
Oxygen density & $\mathrm{lbm} / \mathrm{ft}^{3}$ & 71.2 & 71.2 & 71.2 & 75.0 & 75.0 & 75.0 \\
O/F & 6 & 5.5 & 5.2 & 6.3 & 5.8 & 5.5 \\
$\begin{array}{l}\text { Theoretical specific } \\
\text { impulse (Ivac) } \\
\text { Delivered specific } \\
\text { impulse (Isp) }\end{array}$ & seconds & 488.4 & 489.2 & 489.3 & 487.2 & 488.5 & 488.8 \\
\hline
\end{tabular}


TABLE III.-LAUNCH VEHICLE PERFORMANCE CALCULATIONS FOR A HYDROGEN/OXYGEN FUELED UPPER STAGE USING DENSIFIED PROPELLANTS

\begin{tabular}{|c|c|c|c|c|c|c|c|c|}
\hline Parameter & Symbol & Units & $\begin{array}{c}1 \\
\text { Baseline }\end{array}$ & $\begin{array}{c}2 \\
\text { TP LH2 }\end{array}$ & \begin{tabular}{|c|}
3 \\
Hydrogen \\
50 percent \\
solids \\
\end{tabular} & $\begin{array}{c}4 \\
\text { Oxygen } \\
140 \mathrm{R}\end{array}$ & $\begin{array}{c}5 \\
\text { TP LH2 } \\
\text { 140 R LOX }\end{array}$ & $\begin{array}{c}6 \\
50 \text { percent } \\
\text { SLH2 } \\
\text { 140 R LOX }\end{array}$ \\
\hline $\begin{array}{l}\text { First stage } \\
\text { Initial mass } \\
\text { Propellant mass } \\
\text { Dead weight mass (estimated) } \\
\text { Payload mass } \\
\text { Engine performance } \\
\text { Second stage } \\
\text { Initial mass } \\
\text { Propellant mass hydrogen } \\
\text { Propellant mass oxygen } \\
\text { Propellant mass total } \\
\text { Dead weight mass (estimated) } \\
\text { Payload mass } \\
\text { Engine performance } \\
\text { Engine mixture ratio } \\
\text { Delta velocity } \\
\text { Increase in payload mass }\end{array}$ & $\begin{array}{l}\mathrm{m}_{01} \\
\mathrm{~m}_{\mathrm{p} 1} \\
\mathrm{~m}_{\mathrm{d} 1} \\
\mathrm{~m}_{1,1} \\
\text { Isp }_{1} \\
\mathrm{~m}_{02}\end{array}$ & $\left.\right|_{\text {seconds }} ^{\mathrm{lbm}}$ & $\begin{array}{r}554166 \\
450000 \\
45000 \\
59166 \\
264 \\
\\
59166 \\
5666 \\
34000 \\
39666 \\
4500 \\
15000 \\
466.5 \\
6.0 \\
30882 \\
0\end{array}$ & $\begin{array}{r}554858 \\
450000 \\
45000 \\
59858 \\
264 \\
\\
59858 \\
6153 \\
34000 \\
40153 \\
4500 \\
15205 \\
467.3 \\
5.5 \\
30882 \\
\\
205\end{array}$ & $\begin{array}{r}555335 \\
450000 \\
45000 \\
60335 \\
264 \\
\\
60335 \\
6510 \\
34000 \\
40510 \\
4500 \\
15325 \\
467.4 \\
5.2 \\
30882 \\
\\
325\end{array}$ & $\begin{array}{r}556472 \\
450000 \\
45000 \\
61472 \\
264 \\
\\
61472 \\
5666 \\
35802 \\
41468 \\
4500 \\
15504 \\
465.4 \\
6.3 \\
30882 \\
\\
504\end{array}$ & $\begin{array}{r}557189 \\
450000 \\
45000 \\
62189 \\
264 \\
\\
62189 \\
6153 \\
35802 \\
41955 \\
4500 \\
15734 \\
466.6 \\
5.8 \\
30882 \\
\\
734 \\
\end{array}$ & $\begin{array}{r}557676 \\
450000 \\
45000 \\
62676 \\
264 \\
\\
62676 \\
6510 \\
35802 \\
42312 \\
4500 \\
15864 \\
466.9 \\
5.5 \\
30882 \\
864\end{array}$ \\
\hline
\end{tabular}

increases by $205 \mathrm{lb}$ of payload. When 50 percent slush hydrogen is used the payload mass increases by $325 \mathrm{lb}$. When densified oxygen at $140^{\circ} \mathrm{R}$ is used the payload mass increases to $504 \mathrm{lb}$. When both triple point liquid hydrogen and $140^{\circ} \mathrm{R}$ liquid oxygen are used together an additional $734 \mathrm{lb}$ of payload can be obtained over the baseline vehicle. Finally, when 50 percent slush hydrogen and $140{ }^{\circ} \mathrm{R}$ liquid oxygen are used the payload gain is $864 \mathrm{lb}$.

It is important to point out that in case $4,140^{\circ} \mathrm{R}$ liquid oxygen, the $\mathrm{O} / \mathrm{F}$ climbs to 6.3 . The increased mixture ratio raises concerns about higher combustion temperatures and excess oxygen near the wall which can reduce the lifetime of the combustion chamber. The analysis presented here shows that if hydrogen, densified to the triple point, is used in conjunction with densified oxygen the $\mathrm{O} / \mathrm{F}$ stays below the nominal and thermal damage to the engine is no longer an issue.

\section{Concluding Remarks}

Densified propellants offer vehicle manufacturers more payload flexibility and weight margin than other advanced technologies for the same amount of investment. By subcooling $\mathrm{LH}_{2}$ and $\mathrm{LOX}$ to near triple point conditions, a substantial increase in vehicle performance can be realized without the 2 phase fluid complexities of a slush mixture. The vehicle performance analysis presented in this report indicates a payload gain of up to 5 percent $(734 \mathrm{lb})$ if both densified $\mathrm{LH}_{2}$ and $\mathrm{LOX}$ are used. While this number does not account for the weight penalty of incorporating a recirculation manifold and disconnect for the densification GSE, it still represents the potential for significant payload gains with only minor tank redesign and a nonrecurring investment in launch pad ground support equipment.

In addition the test results presented in this paper demonstrate that an aerospace industry standard-the RL10 rocket engine can be ignited with densified $\mathrm{LH}_{2}$ with no hardware changes. Additional testing is required to optimize the ignition sequence for both densified $\mathrm{LH}_{2}$ and LOX, but this successful ignition demonstrates a vital step in bringing densified propellants to a technology readiness level of 6 (system/subsystem model or prototype demonstration in a relevant environment).

\section{Acknowledgments}

The authors would like to thank Mr. Michael L. Meyer of NASA Lewis for helping to conduct the engine analysis. The authors would also like to acknowledge and thank Mr. Jim Brown of Pratt \& Whitney and Mr. Mark Berger of McDonnell Douglas Aerospace for allowing us to utilize the RL10B-2 rocket for our hot fire ignition tests. We also want to thank Ms. Mary Wadel, and Mr. Mike Binder of the NASA Lewis Research Center, Mr. Bob Grabowski and Mr. Richard Patz of Pratt \& Whitney Government Engines \& Space Propulsion, and Mr. Javier Vasquez of McDonnell Douglas for sharing their rocket engine test experience in helping to pick favorable ignition conditions. We also want to acknowledge the engineers and technicians of Sierra Lobo, Inc. Engineering and Technical Services for their dedication to advancing U.S. aerospace technology through testing. 


\section{Appendix A}

\section{Vehicle Performance Calculations}

The vehicle performance calculations are made using the two stage rocket shown in Eq. (1). The rocket equation is derived from Newtons second law of motion $\mathrm{F}=$ ma. The form that is used is taken from Ref. 3 and does not take into account drag force and gravity force.

$$
\Delta v=(\text { Ispg })_{1} \ln \left(\frac{1}{\delta_{1}+\lambda_{1}}\right)+(\text { Isp g })_{2} \ln \left(\frac{1}{\delta_{2}+\lambda_{2}}\right)
$$

The $\Delta \mathrm{V}$ is the change in velocity that is required to reach and maintain a circular orbit at a given altitude. The initial velocity is assumed zero at the launch site. A typical value of $\Delta \mathrm{V}$ required to maintain $\mathrm{LEO}$ is around $25000 \mathrm{ft} /$ sec. The $\Delta V$ used in this analysis is $30882 \mathrm{ft} / \mathrm{sec}$. This higher value of $\Delta V$ is used in Eq. (1) to compensate for gravity force and drag force. The value of the gravitational constant used in the analysis was $32.2 \mathrm{ft} / \mathrm{sec}^{2}$.

The dead weight ratio is calculated in Eq. (2) and the payload ratio is calculated in Eq. (3).

$$
\begin{gathered}
\delta_{\mathrm{i}}=\frac{\mathrm{m}_{\mathrm{d}_{\mathrm{i}}}}{\mathrm{m}_{\mathrm{O}_{\mathrm{i}}}} \\
\lambda_{\mathrm{i}}=\frac{\mathrm{m}_{\mathrm{L}_{\mathrm{i}}}}{\mathrm{m}_{\mathrm{0}_{\mathrm{i}}}}
\end{gathered}
$$

The initial mass of the first stage is calculated in Eq. (4) and the initial mass of the second stage is given by Eq. (5).

$$
\begin{gathered}
\mathrm{m}_{0_{1}}=\mathrm{m}_{\mathrm{L}_{1}}+\mathrm{m}_{\mathrm{d}_{1}}+\mathrm{m}_{\mathrm{p}_{1}} \quad \text { where } \quad \mathrm{m}_{\mathrm{L}_{1}}=\mathrm{m}_{\mathrm{O}_{2}} \\
\mathrm{~m}_{\mathrm{O}_{2}}=\mathrm{m}_{\mathrm{L}_{2}}+\mathrm{m}_{\mathrm{d}_{2}}+\mathrm{m}_{\mathrm{p}_{2}}
\end{gathered}
$$

\section{References}

1. Santiago, J.R., "Evolution of the RL10 Liquid Rocket Engine for a New Upperstage Application," AIAA Paper 96-3013, July, 1996.

2. Gordon, S., and McBride, B.J., "Computer Program for Calculation of Complex Chemical Equilibrium Compositions, Rocket Performance, Incident and Reflected Shocks, and Chapman-Jouguet Detonations," NASA SP-273, Interim Revision, March 1976, Updated Version CET89.

3. Oates, G.C., Aerothermodynamics of Gas Turbine and Rocket Propulsion, American Institute of Aeronautics and Astronautics, 1994.

4. Wilson, A., editor, Jane's Space Directory, 12th Edition, 1996-97. 

Public reporting burden for this collection of information is estimated to average 1 hour per response, including the time tor reviewing instructions, searching existing data sources, gathering and maintaining the data needed, and completing and reviewing the collection of information. Send comments regarding this burden estimate or any other aspect of this collection of information, including suggestions for reducing this burden, to Washington Headquarters Services, Directorate for Information Operations and Reports, 1215 Jefferson Davis Highway, Suite 1204, Arlington, VA 22202-4302, and to the Office of Management and Budget, Paperwork Reduction Project (0704-0188), Washington, DC 20503.

\begin{tabular}{|l|l|l}
\hline 1. AGENCY USE ONLY (Leave blank) & $\begin{array}{c}\text { 2. REPORT DATE } \\
\text { July } 1997\end{array}$ & $\begin{array}{c}\text { 3. REPORT TYPE AND DATES COVERED } \\
\text { Technical Memorandum }\end{array}$
\end{tabular}

\section{TITLE AND SUBTITLE}

Hot Fire Ignition Test With Densified Liquid Hydrogen Using a RL10B-2

Cryogenic $\mathrm{H}_{2} / \mathrm{O}_{2}$ Rocket Engine

\section{AUTHOR(S)}

Nancy B. McNelis and Mark S. Haberbusch

\section{PERFORMING ORGANIZATION NAME(S) AND ADDRESS(ES)}

National Aeronautics and Space Administration

Lewis Research Center

Cleveland, Ohio 44135-3191

9. SPONSORINGMONITORING AGENCY NAME(S) AND ADDRESS(ES)

National Aeronautics and Space Administration

Washington, DC 20546-0001

\section{SUPPLEMENTARY NOTES}

Prepared for the 33rd Joint Propulsion Conference \& Exhibit cosponsored by AIAA, ASME, SAE, and ASEE, Seattle, Washington, July 6-9, 1997. Nancy B. McNelis, NASA Lewis Research Center and Mark S. Haberbusch, Ohio Aerospace Institute, (presently at Sierra Lobo Inc., Propellant Densification Systems, 20525 Homestead Park Drive, Strongsville, Ohio 44136). Responsible person, Nancy B. McNelis, organization code 5870, (216) 977-7474.

128. DISTRIBUTIONAVAILABILITY STATEMENT

Unclassified - Unlimited

Subject Category 28

This publication is available from the NASA Center for AeroSpace Information, (301) 621-0390.

\section{ABSTRACT (Maximum 200 words)}

Enhancements to propellants provide an opportunity to either increase performance of an existing vehicle, or reduce the size of a new vehicle. In the late 1980's the National AeroSpace Plane (NASP) reopened the technology chapter on densified propellants, in particular hydrogen. Since that point in time the NASA Lewis Research Center (LeRC) in Cleveland, Ohio has been leading the way to provide critical research on the production and transfer of densified propellants. On October 4, 1996 NASA LeRC provided another key demonstration towards the advancement of densified propellants as a viable fuel. Successful ignition of an RL10B-2 engine was achieved with near triple point liquid hydrogen.

\begin{tabular}{|c|c|}
\hline 14. SUBJECT TERMS \\
Densified propellants; Rocket ignition \\
\hline $\begin{array}{c}\text { 17. SECURITY CLASSIFICATION } \\
\text { OF REPORT } \\
\text { Unclassified }\end{array}$ & $\begin{array}{c}\text { 18. SECURITY CLASSIFICATION } \\
\text { OF THIS PAGE } \\
\text { Unclassified }\end{array}$ \\
\hline
\end{tabular}

\begin{tabular}{|c|c|}
\hline & $\begin{array}{c}\text { 15. NUMBER OF PAGES } \\
12\end{array}$ \\
\hline & $\begin{array}{r}\text { 16. PRICE CODE } \\
\mathrm{A03}\end{array}$ \\
\hline $\begin{array}{l}\text { 19. SECUAITY CLASSIFICATION } \\
\text { OF ABSTRACT } \\
\text { Unclassified }\end{array}$ & 20. LIMITATION OF ABSTRACT \\
\hline
\end{tabular}

